\title{
Enforcement of Fundamental Rights in National Constitutions: Resolving the Conflict of Jurisdiction between the Federal High Court and State High Court in Nigeria
}

\author{
Eje Adakole Odike ${ }^{1}$, Alero Akujobi ${ }^{2}$ \\ ${ }^{1}$ Department of Jurisprudence \& International Law, Ebonyi State University, Abakaliki, Nigeria \\ ${ }^{2}$ Faculty of Law, National Open University of Nigeria, Abuja, Nigeria \\ Email: atakujobi@yahoo.com
}

How to cite this paper: Odike, E. A., \& Akujobi, A. (2018). Enforcement of Fundamental Rights in National Constitutions: Resolving the Conflict of Jurisdiction between the Federal High Court and State High Court in Nigeria. Beijing Law Review, 9, 53-66.

https://doi.org/10.4236/blr.2018.91004

Received: December 25, 2017

Accepted: March 6, 2018

Published: March 9, 2018

Copyright $\odot 2018$ by authors and Scientific Research Publishing Inc. This work is licensed under the Creative Commons Attribution International License (CC BY 4.0).

http://creativecommons.org/licenses/by/4.0/

\begin{abstract}
Fundamental human rights are those natural or human rights that are guaranteed to individuals as a citizen of a free and civilized state. They are incorporated in the supreme or basic law of a country as fundamental human rights. This paper examines the conflict of jurisdictions between the federal high court and the state high courts in the enforcement of fundamental human rights with particular emphasis on how the Nigerian case law has contributed to the confusion. To resolve the issue, the paper surveyed the position of enforcement of fundamental human rights in few other common law jurisdictions such as India, Pakistan and Ghana, and concluded that in Nigeria, the federal high court only has jurisdiction to enforce fundamental human rights arising from a cause of action that falls within its limited exclusive jurisdiction.
\end{abstract}

\section{Keywords}

Ordinary Right, Rights of Man, Natural Rights, Human Rights, Fundamental Human Rights, Constitution, Jurisdiction, High Court, Enforcement

\section{Introduction}

Chapter four of the Constitution of the Federal Republic of Nigeria, 1999 (as amended in 2011) contains the fundamental human rights guaranteed to all $\mathrm{Ni}$ gerians, and to some extent, non-Nigerian residing within the geographical sphere of the country. The enshrinement of fundamental human rights in the constitution of Nigeria, though laudable, has of recent become a controversial 
issue. This is due to the contradiction and/or controversy associated with the enforcement procedure of those rights, as provided both in the constitution and the Fundamental Rights (Enforcement Procedure) Rules, 1979. While the constitution created two categories of High Courts in Nigeria with different jurisdictions, it granted an open check to alleged victims of human rights violations to apply to the "high court" to enforce their rights without delineating which high court and the circumstances that would qualify the high court to entertain the application.

The contradiction and/or controversy generated by the issue of which court, that is, the state high court or the federal high court, in Nigeria, that have jurisdiction on matters concerning enforcement of fundamental human right violations has shown itself in a flurry of cases. For example, in Bronik Motors Ltd v. Wema Bank Ltd ; the Supreme Court of Nigeria held that both the federal high court and the state high court had concurrent jurisdiction in case of enforcement of fundamental right allegedly violated.

Later on, in Tukur v. Government of Gongola State ${ }^{2}$ the Supreme Court of Nigeria per Obaseki JSC (as he then was), in a seemingly contradictory judgment, held that:

Since the jurisdiction conferred by section 42 (2) of the constitution is a special jurisdiction and made subject to the provisions of the constitution, the enforcement of the fundamental rights in matters outside the jurisdiction of the Federal High Court is not within and cannot be in the contemplation of the section. If any consideration and determination of the civil rights and obligations in matters outside jurisdiction of the Federal High Court inextricably involves a consideration and determination of the breach or threatened breach of any of the fundamental right provisions, the exercise of jurisdiction which the Federal High Court does not possess is mouthy. The lack of jurisdiction inexorably nullifies the proceedings and judgment. It is therefore an exercise in futility.

The above contradiction also reared its head in the case of Jack $v . U N A M^{\beta}$, and other cases ${ }^{4}$. In the case of Jack v. UNAM (Supra), Grace Jack was employed by the University of Agriculture, Makurdi (Respondent) as a clinic attendant. She was later transferred to the bursary department of the Respondent's university where she remained until she was served a letter of suspension. What led to her suspension was the acceptance by the Respondent of the outcome of an internal inquiry it set up to determine her involvement or otherwise in some misconduct regarding the collection and issuance of receipt for fees and other dues from students. The panel of inquiry found her guilty of the misconduct and the Respondent accordingly dismissed her from its employment.

1(1983)1F.W.R463.

${ }^{2}(1989) 4$ N.W.L.R (pt. 117) 517 at 547.

${ }^{3}(2005) 5$ N.W.L.R (pt.865) at 225-226 particularly at p. 229.

${ }^{4}$ See also, Gafar v. Govt. Kwara State (2007) 4 N.W.L.R (pt.1024) 37: See also, Gov., Kwara State v. Lawal (2007) 13 N.W.L.R (pt. 1051)347. Gabriel v. Ukpabio (2008) 3 N.W.L.R (pt. 1073)21. 
Unhappy with that dismissal, the appellant (Grace Jack v. UAM, 2004) filed an action in the High Court of Benue State under the Fundamental Rights (Enforcement Procedure) Rules. She asked the court for an order quashing the letter, an order for payment of accrued salaries and general damages for breach of contract and in the alternative payment of future earnings for 33 years. After address by counsels, the High Court granted the entire appellant's relief, less the alternative. The respondent's appeal to the Court of Appeal was allowed for the reason that by section 230 (1) of Decree 107 of 1993 now section 251 of the constitution, government agency, was not amenable to the jurisdiction of the High Court but that of the Federal High Court.

The appellant's appeal to the Supreme Court of Nigeria was, inter-alia, allowed after the court had considered section 42 (1) (2) and (3) of the 1979 constitution, now section 230 (1) (r) of the 1999 constitution. The Supreme Court per Katsina-Alu JSC (as he then was), held unanimously that:

In the resolution of this issues, I would like to point out that section 42 (1) of the constitution that I have reproduced above has provided the court enforcement of fundamental as enshrined in chapter iv. A person whose fundamental is breached, being breached or about to be breached may therefore apply to high court in that State for redress. Order 1 Rule 2 of the Fundamental Rights (Enforcement Procedure) Rules, 1979, which came into force on $1^{\text {st }}$ January, 1980 defines "court" as meaning "the federal high court or high court of a state", what this means is this: both the federal high court and the high court of a state have concurrent jurisdiction.

The above judgment was agreed to Uwais JSC (as he then was) when he said that:

Section 42 (1) of the constitution is a special provision which deals with matters of fundamental rights... In my view, section 42 (1) is intended to give access to aggrieved party to any high court in a state where an alleged contravention of his fundamental rights has taken place or is about to take place.

These conflicting decisions churned out by Nigerian courts has inescapably embolden lower courts hearing matters on enforcement of fundamental rights to pick and choose whatever diametrically opposed decisions that catches their fancy ${ }^{5}$. This has heightened the need for a legal exposition of the issue to delineate the limit of the jurisdictional competence of either the state high court or the federal high court in hearing and resolving matters involving enforcement of fundamental human rights violations in Nigeria.

\section{Ordinary Right Compared with Human Rights}

A right is that which is proper under the law. It is a liberty protected and en-

${ }^{5}$ See, Obande (2008), Understanding the Concept of Jurisdiction in Nigeria (Enugu: Snaap Press Ltd; 2008) p. 
forced by law, which compels specific person or persons to do or abstain from doing something ${ }^{6}$. In other words, ordinary right is any advantage or benefit vested on a person by a rule of law. A right in that regard or sense is limited to the specific interest recognized and protected by law ${ }^{7}$.

Human rights, as a form of right, unlike ordinary right, transcend the general notion of rights as liberties protected and enforced by law. In contrast to the general notion of right, human rights are broader in perspective because; they embrace all conceivable rights to which a human being can lay a just or valid claim, not necessary on the basis of law, but on the fact that the claimant is a human beings ${ }^{8}$. Human rights are therefore inherent, universal and they transcend sex, race, region and religion. Though, inherent and universal, human rights in its entirety are not usually incorporated as guaranteed human rights in national constitutions.

Historically, the term human rights entered the public parlance after the formation of the United Nations Organization in $1945^{9}$. Shortly after the formation, human rights received recognition and endorsement by the member states of the United Nations, as the principle on which the Organization (the United Nations) would be based. With that recognition and endorsement, the concept of human rights replaced the hitherto existing concept of natural rights, which fell into disuse partly because of religious sentiments and the fact that it had become a subject of great controversy ${ }^{10}$. Within this period too, the term "Right of Man" was briefly used in public discussion to denote natural rights. This too fell into disuse, due to un-relented and acerbic attacks on the concept by female advocates, who rightly or wrongly felt that the idea of "Rights of Man", at best, connotes gender inequality, sexiest inclination, insensitive or at worst, denotes male dominance or chauvinism. Hence, the emergence of human rights in international literature ${ }^{11}$.

The internationalization of human rights took a documented dimension with the progressive codification of internationally recognized human rights in a document called Universal Declaration of Human Rights ${ }^{12}$.

However, none of the provisions of the Declaration constituted an enforceable obligation on the signatory states. This is because; the contents of the declaration were merely persuasive legal-moral rules. This formal declaration of inherent human rights in a document, though not legally binding, was swiftly followed by series of binding treaties such as: the International Covenant on Civil and Polit-

${ }^{6}$ Bryan Garner, Tiger Jackson \& Jeff Newman (eds.) Black's Law Dictionary, $9^{\text {th }}$ Edition, (USA: West Publishing Co. Ltd: 1990) p. 1436.

${ }^{7}$ See, Uwaifo v. AG Bendel State \& Ors (1982) 7.SC. 124 at 273. See also, Afolayan v. Ogunde \& Ors. (1990) 5.N.W.L.R (pt.127) 369 at 391.

${ }^{8}$ This definition takes into consideration the fact that it is not all human rights that are protected and enforced by law.

${ }^{9}$ This was shortly after the brutal termination of the Second World War. The dropping of nuclear bombs in the Japanese cities of Hiroshima and Nagasaki forced the imperial Japanese army to surrender.

${ }^{10}$ See, Odike (2016), Felix's Principles and Practice of Nigeria Legal System (Enugu: Tink Graphics; 2016) p.227.

${ }^{11}$ Ibid.

${ }^{12}$ The Declaration came into being on $10^{\text {th }}$ December, 1948. 
ical Rights, 1966, the International Covenant on Economic, Social and Cultural Rights,1966 and the African Charter on Human and Peoples' Rights, 1981.

The signing of these international treaties by the government of Nigeria left her with no other respectful choice than to internalize the provisions of those treaties in her municipal laws, notably the constitution.

\section{Meaning of Fundamental Human Rights}

Simply put, fundamental human rights are species of human rights that are enshrined or incorporated in national constitutions as constitutional guarantees. Their incorporation elevates them from the status of enforceable non rights to enforceable rights, thereby assuring their place of pride among municipal laws of a Country. As superior rights, they are above ordinary right or other types of human rights that are not so enshrined or incorporated as fundamental objectivities in Chapter two of the Constitution of rights. Essentially the contents of Chapter two of the extant Constitution of Nigeria are arrays of social-economic and social-cultural rights that are not regarded as enforceable rights, but legal moral laws, which the Nigeria State is directed to achieve as a matter of fundamental objectives of State Policy

Consequently, fundamental human rights are rights that protect every person against abuse of powers and unfair treatment within the geo-political domain of the grundnorm. The importance of the protection and freedom that fundamental human rights guarantee is the creation of conducive social environment for individual development within his or her society.

Although, fundamental rights are granted as basic freedoms to citizens, most national constitutions distinguish between citizens and non-citizen in the enjoyment of certain fundamental rights. For instance, freedom of speech and the press $^{13}$, and the right to acquire movable and immovable property anywhere within the country ${ }^{14}$ are normally guarantees to citizens only, while rights of fair hearing ${ }^{15}$, and freedom of thought, conscience and religion ${ }^{16}$, to mention but a few, are granted equally to Nigerians and non Nigerians.

Fundamental human rights as constitutional guarantees are explicitly or implicitly substantial, positive or negative rights intended to serve the following purposes:

1) Prevent the executive organ of government from acting arbitrarily;

2) Assuage the feeling of domination and ensure protection and security to various types of minorities within a nation; and

3) Promote and foster social realization by establishing the conditions necessary for achieving justice, civil and economic development ${ }^{17}$.

\footnotetext{
${ }^{13}$ See, section 39. Constitution, Federal Republic of Nigeria, 1999 (as amended in 2011).

${ }^{14}$ Section 43. Ibid.

${ }^{15}$ Section 36. Ibid.

${ }^{16}$ Section 38. Ibid.

${ }^{17}$ See, Odike (2007), "The Role of the Rule of Law in Democracy, Good Governance and Sustainable Development". Enugu State University of Science and Technology Journal of Public Law, Volume 1. No1. 2007. p.27.
} 
Fundamental rights are of three categories. And they are:absolute rights(such as right to equality and ownership of properties); rights that can be restricted; and rights which are principally left to the legislature to confirm ${ }^{18}$.

The development of constitutionally guaranteed fundamental rights in national constitutions was inspired by historical examples such as the English Bill of Rights, 1787 and the French Declaration of the Rights of Man. These essential rights are enshrined in chapter four of the Constitution of the Federal Republic of Nigeria 1999 as Fundamental Human Rights ${ }^{19}$. They include right to life ${ }^{20}$; right to dignity of human person ${ }^{21}$; right to personal liberty ${ }^{22}$; right to fair hearing $^{23}$; right to private and family life ${ }^{24}$; right to freedom of thought, conscience and religion ${ }^{25}$; right to freedom of expression and the press $^{26}$; right to peaceful assembly and association ${ }^{27}$; right to freedom of movement ${ }^{28}$; right to freedom of discrimination ${ }^{29}$; right to acquire and own immovable property anywhere in Nigeria $^{30}$; and freedom from compulsory acquisition of property ${ }^{31}$.

Generally, fundamental human rights are enshrined in the constitution because; they are considered essential for the development and preservation of individual dignity and they are the harbinger of liberal democracy, because; individual freedoms are the essential features or core features of that form of government. There is no doubt that the freedoms fundamental human rights guarantees in the long run, promote and ensure social, economic and cultural conditions that support growth and development.

\section{Fundamental Human Rights Enforcement in Nigeria: Settling the Jurisdictional Conflict between the Federal High Court and the State High Court}

The Constitution of the Federal Republic of Nigeria 1999 and the Fundamental Human Rights Enforcement Procedure, 1979 provides the mechanism for enforcement of fundamental human rights violation in Nigeria. The said laws empowers any person who alleges that his or her rights will be, has been or is being infringe upon can go to the high court and sue for the enforcement of his or her violated rights. Section 46(1) of the Constitution of the Federal Republic of Ni-

${ }^{21}$ Section 34.ibid.

${ }^{22}$ Section 35. Ibid.

${ }^{23}$ Section 36. Ibid.

${ }^{24}$ Section 37. Ibid.

${ }^{25}$ Section 38. Ibid.

${ }^{26}$ Section 39. Ibid.

${ }^{27}$ Section 40 . Ibid.

${ }^{28}$ Section 41. Ibid.

${ }^{29}$ Section 42. Ibid.

${ }^{30}$ Section 43. Ibid.

${ }^{31}$ Section 44. Ibid.
}

${ }^{19}$ For example, most of the provisions of the International Covenant on Civil and Political Rights and International Covenant on Economic, Social and Cultural Rights were respectively domesticated as Fundamental Human Rights in Chapter 4 and Fundamental Objectives in Chapter 2 of the 1999 Constitution of Nigeria.

${ }^{20}$ Section 33, Constitution of the Federal Republic of Nigeria, 1999 (as amended) 2011. 
geria, 1999 appears to be the enabling provision for the enforcement of fundamental human rights in Nigeria. It provides that:

Any person who alleged that any of the provisions of chapter 4 dealing with fundamental human rights has been, is being, or is likely to be contravened in any state in relation to him may apply to the high court in that state for redress.

The provision is further espoused by the Fundamental Rights (1979) (Enforcement Procedure) Rules, 1979 made by the Chief Justice of Nigeria pursuant to section 42(3) of the defunct 1979 Constitution of Nigeria, now section 46(3) of the extant 1999 Constitution $^{32}$. Specifically for purpose of determining the conflict of jurisdiction between the federal and state high courts in Nigeria, section 46(2) of the 1999 constitution provides that:

Subject to the provisions of this constitution, a High Court shall have original jurisdiction to hear and determine any application made to it in pursuance of the provision of this section and may make such order, issue such writs and give such directions as it may consider appropriate for the purpose of enforcing or securing the enforcement within the state of any right to which the person who makes the application maybe entitled under this chapter.

This provision seems very clear in determining the court that has jurisdiction to entertain cases for enforcement of fundamental human rights in Nigeria, which is the High Court. However, the provision failed to designate the appropriate high court in which such issues would be brought given the existence of two high courts in the constitution that is, the federal high court and state high courts. This lacuna has led to several jurisdictional disputes that have resulted in conflicting decisions of both the Supreme Court and Court of Appeal regarding the competence of the two high courts to enforce fundamental human rights in Nigeria.

The judicial authorities that most notably demonstrate the confusion in the jurisdictional competence of the two courts are the decisions in Bronik Motors Ltd. v. Wema Bank Ltd., Turkur v. Government of Gongola State (1989); and Jack v. UAM. The jurisdictional conflict between the federal and state high courts in respect of fundamental human rights is actually exacerbated by the interpretations of sections 272(1) and 251(1) of the 1999 constitution. In the said section, the constitution grants unlimited jurisdiction to the high court of the states to determine any civil or criminal matter brought before it, which invariably includes enforcement of fundamental human rights. However, the section limits the jurisdiction of the state high courts on specific matters, which section 251(1) of the constitution exclusively reserves for jurisdiction of the federal high ${ }^{32}$ See, the case of Barwo Radio TV Corporation V. Egbu (1991)2 N.W.L.R (pt.171)8, where the court held that the Fundamental Rights (Enforcement Procedure) Rules are applicable to long breach of the fundamental human rights provisions enshrined in the Constitution of the Federal Republic of Nigeria, 1999 (as amended in 2011). 
court.

Section 272(1) provides as follows:

Subject to the provisions of section 251 and other provisions of these constitution, the High Court of a State shall have jurisdiction to hear and determine any civil proceedings in which the existence or extent of a legal right, power, duty, liability, privilege, interest, obligation or claim is in issue or to hear and determine any criminal proceedings involving or relating to any penalty, forfeiture, punishment or other liability in respect of an offense committed by any person.

Section 251(1) on the other hand, provides that:

Notwithstanding anything to the contrary contained in the constitution, and in addition to such other jurisdiction, as may be conferred upon it by an Act of the National Assembly, the Federal High Court shall have and exercise jurisdiction to the exclusion of any other court in civil causes and matters [ relating to or connected with sub-sections (a) - (s)].

The determination of the words "notwithstanding" and "subject to" used in sections 251(1) and section 272(1) above, appears to hold the key to understanding the extent of the jurisdictional competence of the federal high court in enforcement of fundamental human rights violation in Nigeria vis-à-vis the state high courts. The word "notwithstanding" in section 251(1) seems to limit the jurisdiction of the federal high court in the enforcement of fundamental human rights to the subject matter contain in section 251(1)(a)-(s) only. On the other hand, the word "subject to" in section 272(1) amplifies the general jurisdiction of the State High Court to enforce every violation of fundamental human rights except those within the subject matter of section 251(1) of the constitution.

The Supreme Court per Uwaifo JSC (as he then was) in NDIC v. Okem Enterprises Ltd (2004) $)^{33}$ explained the legal effect and import of the word "notwithstanding" in a legislation. In his immutable words:

When the term "Notwithstanding" is used in a section of a statute, it is meant to exclude an impinging or impeding effect of any other provisions of the statute or other subordinate legislation so that the said section may fulfill itself.

This means that no provision of the 1999 constitution of Nigeria is capable of hindering section 251(1) of the constitution ${ }^{34}$. Stretch further, the use of the phrase "notwithstanding anything to the contrary" in section 251(1) imports that the special jurisdiction conferred on the Federal High Court by section 46(2) of the same constitution to enforce fundamental human rights violations in Nigeria, is only exercisable to the extent or scope of section 251(1) (a)-(s). Thus, it amounts to a misplaced argument to contest that section 46(2) of the

${ }^{33}(2004)$ W.L.R (pt.880)107.

${ }^{34}$ See, Nyako v. Ardo (2013) L.P.E.R-2.0848. 
same constitution confers unlimited jurisdiction on the Federal High Court to enforce Fundamental Human Rights violation in Nigeria.

Going by these constitutional provisions therefore, the matchless truth is that section 46(2) has legally made itself subservient to the general provisions of section 251(1) of the 1999 constitution of Nigeria. This is logical for the special jurisdiction conferred on the High Court by section 46(2) of the constitution cannot overreach the general provisions otherwise coined as exclusive jurisdiction of the Federal High Court ${ }^{35}$. This is apt because "subject to" is commonly used in a legislation purposely to introduce a limitation. Justice Niki Tobi lends his weighty judicial voice to the above conclusion in Yusufuv \& Obasanjo (2003) ${ }^{36}$ when he opined that:

Subject to is often used in statute to introduce a condition, a provision, a restriction, a limitation. The expression subordinates the provision(s) of the subject section to the section referred to which is intended not to be affected by the provision(s) of the later.

Thus, while the general jurisdiction conferred on the Federal High Court by section 251(1) of the 1999 constitution of Nigeria, is to be interpreted and exercised independently, the special jurisdiction conferred on the High Court by section 46(2), of the same constitution, relating to fundamental human rights enforcement is limited to the extent of the subject matter outlined in section 251(1) (a) - (s) of the constitution. This means in essence that where a dispute involving violation of fundamental human rights does not originate from any of the subject matter listed under section 251(1) (a) - (s), the Federal High Court err in law if it assumes jurisdiction thereon in contradistinction to the state high court ${ }^{37}$. This is because one of the prerequisites of a court in the exercise of jurisdiction is that the subject matter of the action must fall within its jurisdiction and there should be no evidence in the dispute, which prevents the court from the exercise of its jurisdiction ${ }^{38}$. Thus, in determining the extent of the jurisdictional competence of the Federal High Court, one needs to critically look at the fundamental rights enforcement writs $^{39}$, and ensure that the claimant's claim is the main claim and not an auxiliary claim.

In the case of Augustine Nwoko Chibuike v. Commissioner of Police Imo State \& $3 \mathrm{Ors}^{40}$, the applicant, Chibuike claimed against the respondents, the following reliefs:

1) A declaration that the detention of the applicant by policemen under the $1^{\text {st }}$ and $2^{\text {nd }}$ respondents for six (6) days between $13^{\text {th }}$ September, 2014 to the $18^{\text {th }}$ September 2014, in Cell 5, otherwise known as VIP cell of the State CID, Owerri

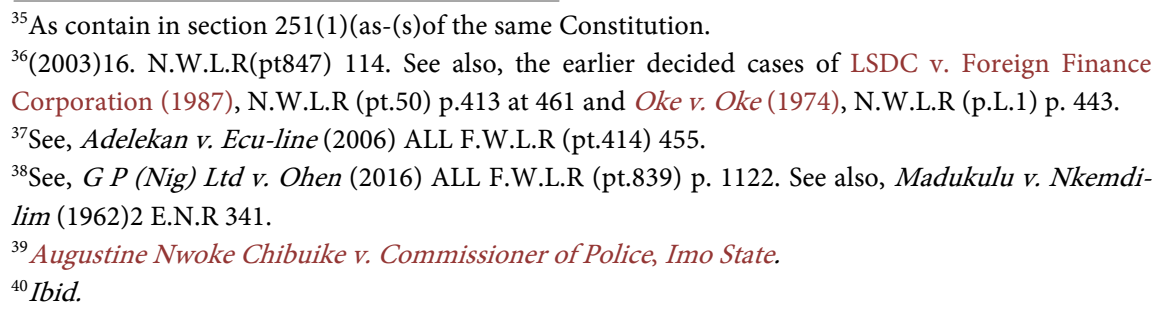


and at the instigation of the $3^{\text {rd }}$ respondent without any justification amounted to a flagrant abuse and infringement of the applicant's fundamental rights contrary to section 34(1) and 35(1) of the Constitution of the Federal Republic of Nigeria 1999 as amended.

2) A declaration that the detention of the applicant for 6 days in Cell 5 of the state CID on the instruction of the second respondent over tenancy related matter amounted to an abuse of power, illegal, unconstitutional and infraction of the fundamental rights of the applicant to his personal liberty and the dignity of his person contrary to section 34(1) and 35(1) of the Constitution of the Federal Republic of Nigeria, 1999 as amended.

3) A declaration that the second respondent's conduct when she assumed power as a police officer to sit over and forcefully recover money and settle tenancy related matter between the $3^{\text {rd }}$ respondent and the applicant amounted to an abuse of power, illegal, and an infringement of the fundamental rights of the applicant.

4) A declaration that the continuous detention, seizure and impoundment of the applicant's vehicle till date by the second respondent in a bid to forcefully recover monies meant for rent/tenancy from the applicant and for the $3^{\text {rd }}$ respondent amounts to abuse of power and an infringement on the fundamental rights of the applicant.

5) An order of court to release the applicant with immediate effect and without any condition attached, the vehicle, a Toyota Sienna with Registration No. 8373096 and Chassis No. 4T32F13CO3U522O63 belonging to Monde Onuoha, the applicant's cousin which was unlawfully impounded by the second respondent till date.

6) An order of injunction restraining the respondents, their agents and privies from further harassing, intimidating, arresting detaining and forcefully recovering monies from the applicant for the $3^{\text {rd }}$ respondent.

7) An order that the respondents should tender an apology to the applicant in 3 widely read national dailies; and

8) An order of the sum of ten million naira as damages from the respondents, jointly and severally.

The main fact that gave rise to the above fundamental human rights enforcement proceeding as could be gleaned from the supporting affidavit of the applicant are clearly issues of rent and/or tenancy. It is clear from a long line of judicial decision that jurisdiction is determine by the Applicant's claim ${ }^{41}$, the presiding judge in Augustine Nwoko Chibuike v.CO.P. Imo State (supra), Justice Shaibu S.M, being aware of that position of law, asked the respective learned counsels to file further addresses on subject matter jurisdiction in the light of the general provisions of section 251(I)and the special provision of section 46(2) of the 1999 constitution.

\footnotetext{
${ }^{41}$ See, Chief Adeogun v. Hon. Fashogbon (2003) 17.N.W.R.R (pt 1115) p. 149. See also, Lakanmi v. Adene (2003) 10 N.W.L.R (pt. 828) p. 353, and Matari v. Dan Galadima (1993) 3 N.W.L.R (pt.281) p. 266.
} 
The respective learned counsels, except counsel for the $3^{\text {rd }}$ respondent agreed that the Federal High Court have jurisdiction. Consequent on that, the court raised the issue of jurisdiction suomotu and further directed the respective counsels to file further written addresses on the issue of jurisdiction raised by the court $^{42}$. The trial judge raised the issue of jurisdiction suomotu because it is settled law that if a court has no jurisdiction to entertain a matter before it, the result will be that its proceedings on the matter, however well conducted, are a nullity and any decision reach is void abnitio and of no effect whatsoever ${ }^{43}$. The issue of jurisdiction can be raised at any stage of the proceeding ${ }^{44}$. When the court in the above case was convinced that it lacks jurisdiction it rightly held that:

The affidavit evidence placed before the court and the reliefs sought by the applicant ... has its root or origin on matters relating to rent and or tenancy. Those are not matters within the purview of section 251(1) (supra) to which section $46(2)$ is subjected to.

To that end, the court declined jurisdiction because matters of rent and tenancy are not within the purview of sections 251(1) and 46(2) of the 1999 constitution of Nigeria. However, the learned presiding Justice exercised his discretion under section 22(2) of the Federal High Court Act, 2004 and transferred the suit to the High Court of Imo State for hearing and determination.

It is settled law that jurisdiction gives a court competence to decide matters brought before it for determination; and the extent of the court's jurisdiction is prescribed by the statute establishing it, which may expand o limit the jurisdiction. Section 251(1) of the 1999 constitution of Nigeria which imposed exclusive jurisdiction on the Federal High Court also imputed that jurisdiction can be expanded, if and only if, an Act of the National Assembly confers on the Federal High Court additional jurisdiction. So far, that has not been done. Hence, the jurisdiction of the Federal High Court to hear and determine fundamental human rights violation in Nigeria is limited to the subject matter outlined in section 251 (1) (supra). This is the legal essence of the word "shall" used in section 251 (1) earlier cited.

\section{Enforcement of Fundamental Human Rights in National Constitutions of Selected Countries}

The enforcement of Fundamental Human Rights violations in the national constitutions of India and Ghana, to mention but a few, do not attract controversy or contradiction, as we have seen in a number of judicial decisions made by some Nigerian courts. However, there is no doubt that Nigeria, like most nation

\footnotetext{
${ }^{42}$ This is because matters of rent and tenancy are not within the preview of section 251(1) and section 46 (2) of the extant Constitution of Nigeria.

${ }^{43}$ See the case of Lakanmi v. Adene (2003) 10 N.W.L.R (pt.828) p.353. See also, Matari v. Dan Galadinma (1993) 3.N.W.L.R (pt281) p.266.

${ }^{44}$ See, Nnonye V. Anyichie (2005) N.W.L.R (pt. 919) p. 623 and Jerric (Nig)Ltd. UBA PLC (2002) 12 SC (pt.11) p. 113.
} 
states that have incorporated fundamental human rights as part of their basic laws recognized fundamental human rights as superior rights. In fact, in the US case of Union Pacific Co. Ltd v. Botsford (1891) $)^{45}$, the US Supreme Court held that fundamental rights are more sacred than any other rights and thus, should be more carefully protected.

This statement informs the way national constitutions provide for enforcement of fundamental rights, and the respect with which the courts uphold the protection. For instance, in the Nigerian case of Mogaji \& Ors. v. Board of Custom \& Excise $(1982)^{46}$, the court gave deference to fundamental rights in conflict between the plaintiffs and the government. The court held that the actions of the Nigerian custom officers, aided by policemen and soldiers, amounted to violation of the plaintiffs' fundamental right to dignity of human person enshrined in the defunct 1979 constitution of Nigeria ${ }^{47}$.

Generally, constitutions of countries operating different legal systems provide for fundamental rights of their citizens. In the common law tradition, many constitutions including that of India and Pakistan provide for fundamental rights. In the 1949 constitution of the Republic of India for instance, these are enshrined in Articles 19-22, while the Pakistani constitution of 1973 incorporates them in Articles 8-28. Both constitutions regard the provisions as supreme, and any law, custom or usage having the force of law that is inconsistent with them is held to be void. However, the procedure for enforcement of fundamental rights in these constitutions vary dramatically. Thus, Article 32 of the 1949 Indian constitution provides as follows:-

1) The right to move in Supreme Court by appropriate proceedings for the enforcement of the rights conferred by this part is guaranteed.

2) The Supreme Court shall have power to issue directions or orders or writs, including writs in the nature of habeas corpus, mandamus, prohibition, quo warranto and certiorari, whichever maybe appropriate for enforcement of any of the fundamental rights guaranteed.

3) Without prejudice to the powers conferred on the Supreme Court by clause (1) and (2), Parliament may by law empower any other Courts to exercise within the vital limits of its jurisdiction all or any of the powers exercised by the Supreme Court under clause (2).

Besides the Supreme Court as shown above, the High Court of India also plays a role in the enforcement of fundamental rights under Article 226 of the constitution. The provision empowers the High Court to issue writs for the enforcement of fundamental rights violation. However, the jurisdiction of the two courts to issue writs is limited to cases of violation of fundamental rights con-

\footnotetext{
${ }^{45}$ US 250 (1891) 250 at 251.

${ }^{46}(1982)$ 3.SC 552.

${ }^{47}$ Law section 34 of the Constitution of the Federal Republic of Nigeria, 1999 (as amended in 2011). See also, Peter Nemi \& Ors. v. State (1990) SC 303; Iffie v. AG Bendel State (1987) 4.N.W.L.R (pt.67) p.2572 CA; Awolowo v. Minister of Internal Affairs (1962) 22 R 117; Udo Udo v. State (1988) 6 SC; Ajayi v. Zaria Native Authority(1963) 1. N.L.R 169; Kokoro-Owo v. Lagos State Government \& Ors (1995) 6 N.W.L.R (pt. 404) 760 CA (Lagos Division).
} 
tained in Part III of the constitution, although, the High Court has additional jurisdiction to issue writs against contravention of ordinary laws of redress and grievances. Thus, in India, the jurisdiction of the High Court vis-à-vis the Supreme Court on enforcement of fundamental rights appears to be broader. Unfortunately, despite such broader jurisdiction, the territorial jurisdiction of the High Court is limited while the Supreme Courts enjoys very liberal territorial jurisdiction covering the entire territory of Indian. Similarly, in the case of Pakistan, Article 199 of the Pakistani Constitution allows a person whose fundamental rights have been violated to seek redress at the Supreme Court or the High Court.

On the other hand, chapter 5 of the Constitution of the Republic of Ghana 1992 empowers the High Court of Ghana to enforce violation of any of the fundamental rights provisions enshrined in the constitution. The procedure provides for the right of appeal to the Court of Appeal and thereafter to the Supreme Court of Ghana. Under the Ghanaian Constitution the particular court having jurisdiction in the enforcement of fundamental human rights is clearly stated. This is unlike the case under the Constitution of the Federal Republic of Nigeria, 1999 where "high court" means, a matter of fundamental human rights enforcement, two high courts, namely, the federal high court and the state higher court.

\section{Conclusion}

Jurisdiction is a prime factor in the administration of justice. It is the tap root of judicial decisions. Indeed, jurisdiction is what gives the court competence and power to adjudicate over any matter or issues brought before it. Since it is upon jurisdiction that court processes stand, the federal high court cannot assume jurisdiction unless the claimant's claim to secure the enforcement of fundamental rights is the main claim and not merely ancillary claim. This, as stated earlier, must flow from the subject matter ascribed to a court by the enabling law or statute.

The subject matters allotted to the federal high court by section 251(1) and subscribed by section 46(2) of the 1999 constitution of Nigeria are certain and cannot be expanded by the court to assume jurisdiction when the claimant's claim, before it, is not the main claim but ancillary claim. Until the National Assembly exercise its constitutional power and grants the Federal High Court additional power, and in consonance with the last limp of the provisions of section 251(1) of the constitution, the extent of its jurisdictional power is limited to the subject matter listed under section 251(1) (a) - (s). Therefore, any attempt by the federal high court to extend its jurisdictional competence beyond section 257(1) will be held tantamount to an act of illegality, null and void, or an exercise in futility based on the fact that it acted ultra-vires.

\section{References}

Afolayan v. Ogunde \& Ors (1990). 5 N.W.L.R (Pt. 127). 369. 
Ajayi v. Zaria Native Authority (1963). 1 N.L.R. 169.

Augustine Nwoko Chibuike v. C.O.P. Imo State \& 3 Ors (Unreported) Suit No. $\mathrm{FHC} / \mathrm{OW} / \mathrm{CS} / 216 / 2014$.

Awolowo v. Minister of Internal Affairs (1962). LLR 117.

Bronik Motors Ltd. v. Wema Bank Ltd. (1985). 35 NCLR 296.

Chief Adeogunv. Honourable Fushogbon (2003). 17 N.W.L.R (Pt. 719).

Constitution of the Federal Republic of Nigeria (1999). (As Amended).

Fundamental Rights (Enforcement Procedure) Rules, 1979.

Gabriel v. Ukpabio (2008). 3. N.W.L.R (Pt. 1073) 21.

Gafar v. Government of Kwara State (2007). 4 N.W.L.R (Pt. 1024) 37.

Government of Kwara State v. Lawal (2007). 13 N.W.R.L (Pt. 1051) 347.

GraceJack v. UAM. (2004). 5 N.W.L.R (Pt. 865) 517.

Iffie v. A.G Bendel State (1987). 4 N.W.L.R (Pt. 67) 572 CA.

International Covenant on Civil and Political Rights (1966).

International Covenant on Economic, Social and Cultural Rights (1966).

Jerric (Nig) Ltd. v. UBA Plc (2002) 12 SC (Pt. 11).

Kokoro-Owo \& Ors v. Lagos State Government \& Ors. (1995). 6 NWLR (Pt. 404) 760 CA.

Lakanmi v. Adene (2003). 10 N.W.L.R (Pt. 828).

LSDC v. Foreign Finance Corporation (1987). 1 N.W.L.R (Pt. 50), 413.

Matari v. Dan Galadima (1993). 3 N.W.L.R (Pt. 281).

Mogaji \& Ors. v. Board of Custom \& Excise (1982). 3 S.C. 552.

NDIC v. Okem Enterprises Ltd. (2004). 10 N.W.L.R (Pt. 880) 107.

Nnonye v. Anyichie (2005). N.W.L.R (Pt. 919), 623.

Nyako v. Ardo (2013). L.P.E.R-208.

Obande, F. O. (2008). Understanding the Concept of Jurisdiction in Nigeria. Enugu: Snaap Press Ltd.

Odike, E. A. (2007). The Role of the Rule of Law in Democracy, Good Governance and Sustainable Development. Enugu State University of Science and Technology Journal of Public Law, 1, 27.

Odike, E. A. (2016). Principles and Practice of Nigeria Legal System. Enugu: Tink Publishers Ltd.

Oke v. Oke (1974). 1 All N.L.R (Pt. 1).

Peter Nemi \& Ors. v. State (1990). SC 303.

Turkur v. Government of Gongola State (1989). 4 N.W.L.R (Pt. 117) 208.

UdoUdo v. State (1988). $6 S C$.

Union Pacific Co. Ltd v. Botsford U.S. 250 (1891). 250.

Universal Declaration of Human Rights (1948).

Uwaifo v. A.G Bendel State (1982). 7 SC 249.

Yusufuv \& Obasanjo (2003). 16 N.W.L.R (Pt. 847). 